\title{
KOMPARASI ANALISIS KELAYAKAN USAHATANI PENANGKARAN BENIH PADI DAN USAHATANI PADI KONSUMSI DI PROVINSI SULAWESI TENGAH
}

\author{
Muhammad Iqbal $^{1]}$ dan Muhammad Afif Juradi ${ }^{2]}$ \\ ${ }^{1]}$ Peneliti Pusat Sosial Ekonomi dan Kebijakan Pertanian (PSE-KP) \\ Jalah Ahmad Yani 70, Bogor 16161 - E-mail: iqbalrafani@gmail.com \\ ${ }^{2]}$ Peneliti Balai Pengkajian Teknologi Pertanian (BPTP) Provinsi Sulawesi Tengah \\ Jalan Lasoso 52, Biromaru, Palu - E-mail: afif.juradi@gmail.com
}

\begin{abstract}
The existence of rice farming can be generally classified into two-category, namely rice farming for breeding and rice farming for consumption. This article aims at: (1) identifying and describing the rice farming; (2) analyzing the feasibility of rice farming for breeding and consumption; and (3) formulating the development policy of rice farming for breeding and consumption in the locale of the study (Central Sulawesi province). The research result shows that the extent of feasibility of rice farming for breeding $(R C R=1.80)$ was higher than that of rice farming for consumption ( $R C R=1.67)$. Even though the rice farming for breeding was prospective, the sustainability of this rice farming activity would be depended upon demand from farmers and other users, the existing government program, and financial investment capacity of rice farmer breeders. Hence, assuring the demand and providing the favorable price of rice seeds are two important aspects supporting the continuity of rice farming for breeding includes rice farming for consumption in the province of Central Sulawesi.
\end{abstract}

Keywords: rice farming, breeding, consumption, Central Sulawesi

\begin{abstract}
Abstrak: Secara garis besar eksistensi usahatani padi dapat dibedakan atas dua kategori, yaitu usahatani penangkaran benih padi dan usahatani padi konsumsi. Artikel ini bertujuan untuk: (1) mengidentifikasi dan mendeskripsikan keragaan usahatani padi; (2) menganalisis kelayakan usahatani penangkaran benih dan padi konsumsi; dan (3) merumuskan kebijakan pengembangan usahatani penangkaran benih dan padi konsumsi di lokasi penelitian (Provinsi Sulawesi Tengah). Hasil penelitian menunjukkan bahwa tingkat kelayakan usahatani penangkaran benih padi $(R C R=1.80)$ lebih tinggi dibandingkan tingkat kelayakan usahatani benih konsumsi $(R C R=1,67)$. Kendati usahatani penangkaran benih padi cukup prospektif, keberlanjutan kegiatannya antara lain dipengaruhi oleh permintaan terhadap benih padi dari petani dan pengguna lainnya, eksistensi program pemerintah dalam pengadaan benih padi, dan kemampuan modal usaha dari penangkar sendiri. Oleh karena itu, jaminan permintaan dan harga yang kondusif merupakan dua aspek penting dalam menunjang kelangsungan usahatani penangkaran benih padi berikut usahatani padi konsumsi di Provinsi Sulawesi Tengah.
\end{abstract}

Kata kunci: usahatani padi, penangkaran, konsumsi, Sulawesi Tengah

\section{PENDAHULUAN}

\section{Latar Belakang}

Menurut Undang-Undang Republik Indonesia Nomor 12 Tahun 1992 (UU No. 12/1992) tentang Budidaya Tanaman, benih tanaman yang selanjutnya disebut benih adalah tanaman atau bagiannya yang digunakan untuk memperbanyak dan/atau mengembangbiakkan tanaman (Pemerintah RI, 1992). Untuk 
tanaman pangan, khususnya padi, benih merupakan unsur vital dalam upaya peningkatan produksi. Tanpa menggunakan benih yang baik dan bermutu (benih unggul), optimalisasi produksi usahatani padi sulit dicapai.

Secara historis benih unggul telah berperan dalam peningkatan produksi padi sejak era Revolusi Hijau (Green Revolution) hingga periode saat ini (swasembada pangan). Oleh karena itu, untuk mencapai dan mempertahankan swasembada pangan yang berkelanjutan maka perangkat perbenihan harus senantiasa kuat. Salah satu upaya untuk memperkuat perangkat perbenihan tersebut adalah dengan membentuk penangkarpenangkar benih unggul di lapangan (Kementan, 2010).

Dengan adanya petani atau kelompok penangkar (usahatani penangkaran), pengadaan benih padi dapat terlaksana dengan cepat dan tepat sesuai kebutuhan petani pengguna (usahatani padi konsumsi). Kendati demikian, pengadaan benih padi tersebut tidak dapat dilepaskan dari konteks agribisnis. Dengan kata lain, apabila usahatani penangkaran mendatangkan tidak menguntungkan penerimaan yang berarti, maka pengadaan benih padi akan mengalami gangguan. Demikian juga sebaliknya, jika usahatani padi konsumsi tidak mendatangkan penerimaan yang nyata, konsekuensinya penyerapan benih padi menjadi terkendala. Untuk itu diperlukan analisis kelayakan usahatani penangkaran benih padi berikut usahatani padi konsumsi. Analisis masing-masing kategori usahatani tersebut dapat dijadikan salah satu acuan untuk menunjang keberlanjutan pengadaan dan penggunaan benih padi di lapangan.

\section{Perumusan Masalah}

Satu diantara beberapa upaya dalam peningkatan produksi dan produktivitas pertanian (termasuk padi) adalah melalui rekayasa genetik berupa penanaman beberapa benih varietas tanaman. Hal tersebut dilandasi bahwa melalui rekayasa genetik, benih varietas unggul dapat dihasilkan, diantaranya tahan terhadap kondisi alam seperti kekeringan, kebanjiran, serangan organisme pengganggu tanaman (OPT), dan lain-lain.

Kendati berbagai upaya sudah dilakukan, kenyataan menunjukkan bahwa beberapa permasalahan masih tetap muncul dalam hal perbenihan. Permasalahan tersebut antara lain karena relatif rendahnya adopsi petani terhadap pemanfaatan benih. Kondisi tersebut disebabkan oleh beberapa faktor, diantaranya: (1) belum optimalnya diseminasi hasil penelitian; (2) belum cocoknya kesesuaian (compatibility) varietas dengan harapan atau keinginan petani; dan (3) belum berjalannya kelembagaan sistem perbenihan terutama dalam kaitannya dengan insentif bagi para produsen dan penangkar, sistem produksi, dan distribusi benih secara lebih baik.

Kendati pemerintah telah berupaya menyediakan bantuan benih, kenyataan menunjukkan bahwa masih ada beberapa keluhan (complaints) dari para petani terhadap ketatalaksanaan pengelolaannya seperti ketidaktepatan waktu penyediaan dan ketidaksesuaian mutu atau kualitas benih. Kriteria enam (6) tepat penyediaan benih terkait dengan jumlah, mutu, waktu, varietas, tempat, dan harga kurang berjalan optimal. Hal tersebut karena pengorganisasian benih bukan pekerjaan sederhana yang tidak hanya memerlukan tatanan kelembagaan yang kondusif tetapi sekaligus memperhatikan kondisi agroekosistem termasuk jadwal musim tanam serta ketersediaan prasarana dan sarana pendukung.

Antisipasi terhadap permasalahan di atas telah diupayakan yaitu melalui pemberdayaan penangkar benih padi. Salah satu kriteria utamanya adalah implementasi luas areal penangkaran masing-masing di bawah 50 hektar dengan rataan produktivitas benih padi minimal 3 (tiga) ton per hektar per musim tanam. Akan tetapi, analisis kelayakan terhadap usahatani penangkaran benih padi harus tetap diperhatikan terkait dengan kesinambungan kinerjanya.

\section{Tujuan}

Tujuan umum artikel ini adalah untuk menganalisis komparasi kelayakan usahatani penangkaran benih padi dan usahatani padi konsumsi pada lokasi penelitian di Provinsi Sulawesi Tengah. Secara khusus artikel ini bertujuan untuk:

1. Mengidentifikasi dan mendeskripsikan keragaan umum usahatani padi. 
2. Menganalisis kelayakan usahatani penangkaran benih padi dan usahatani padi konsumsi.

3. Merumuskan kebijakan pengembangan usahatani penangkaran benih padi dan usahatani padi konsumsi.

\section{METODOLOGI}

\section{Kerangka Pemikiran}

Kerangka pemikiran artikel ini dapat diperhatikan pada Gambar 1. Secara garis besar eksistensi usahatani padi dapat dibedakan atas dua kategori, yaitu: (1) usahatani penangkaran benih padi; dan (2) usahatani padi konsumsi. Secara teknis, usahatani penangkaran benih padi ditujukan dalam rangka penyediaan benih padi untuk kegiatan usahatani padi konsumsi. Sementara itu, usahatani padi konsumsi dimaksudkan buat pemenuhan kebutuhan atas pangan pokok (beras). Secara ekonomi, baik usahatani penangkaran benih padi maupun usahatani padi konsumsi ditujukan untuk mendatangkan penerimaan (revenue) bagi pengelolanya.

Untuk lebih mendalami eksistensi kedua usahatani tersebut, diperlukan identifikasi dan deskripsi serta sekaligus analisis kelayakannya. Usahatani penangkaran benih padi dan usahatani padi konsumsi yang layak berdasarkan analisis perbandingan penerimaan dan biaya (Revenue Cost Ratio/RCR) dapat menjamin kesinambungan usahatani padi yang pada gilirannya dapat mewujudkan swasembada padi/beras.

\section{Waktu dan Lokasi Penelitian}

Penelitian dilaksanakan pada bulan Desember 2013. Lokasi penelitian adalah dua kabupaten yaitu Donggala dan Parigi Moutong. Kedua kabupaten tersebut (Donggala dan Parigi Moutong) dipilih secara sengaja (purpossive method) sebagai representasi sentra produksi beras diantara tiga kabupaten lainnya (Sigi, Banggai, dan Morowali) di provinsi Sulawesi Tengah.

Masing-masing kabupaten diwakili satu kecamatan dan setiap kecamatan dipresentasikan satu desa. Desa terpilih dalam penelitian ini masing-masing: (1) Desa Pani'i, Kecamatan Damsol, Kabupaten Donggala; dan (2) Desa Dolago Padang, Kecamatan Parigi Selatan, Kabupaten Parigi Moutong. Kedua desa tersebut merupakan representasi usahatani penangkaran benih dan padi konsumsi di lokasi penelitian.

\section{Sumber Data dan Informasi}

Data dan informasi penelitian berasal dari sumber primer dan sekunder. Data dan informasi primer diperoleh dari responden usahatani penangkaran benih padi dan usahatani padi konsumsi. Sementara itu sumber data dan informasi sekunder dikumpulkan dari beberapa institusi terkait seperti Dinas Pertanian, Badan Pengawasan dan Sertifikasi Benih (BPSB), dan Balai Pengkajian Teknologi Pertanian (BPTP).

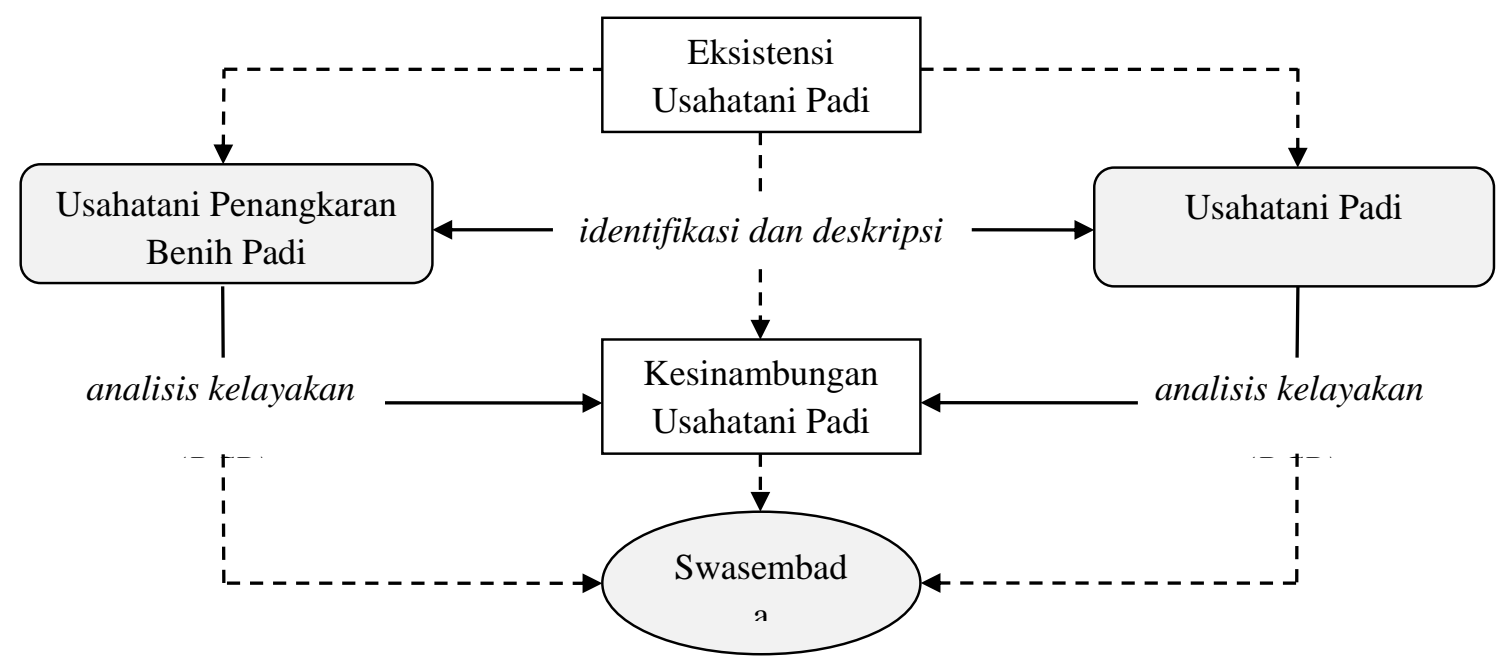

Gambar 1. Kerangka Pemikiran Analisis Kelayakan Usahatani Penangkaran Benih Padi dan Usahatani Padi Konsumsi di Provinsi Sulawesi Tengah 
Data dan informasi primer dikumpulkan melalui wawancara terhadap 6 responden usahatani penangkaran benih padi dan 60 responden usahatani padi konsumsi, menggunakan daftar pertanyaan (questionnaire), panduan pertanyaan (guideline), dan pengamatan (observation) di lapangan. Sementara itu, data dan informasi sekunder berasal dari dokumentasi laporan dan catatan diskusi pada masing-masing institusi terkait.

\section{Analisis Data dan Informasi}

Data dan informasi diolah secara tabulasi silang dan dianalisis secara deskriptif. Sementara itu, kelayakan usahatani baik penangkaran benih padi maupun padi konsumsi di lokasi penelitian masing-masing dianalisis menggunakan metode perbandingan antara penerimaan dan biaya (Revenue Cost Ratio/RCR). Metoda ini merupakan salah satu cara sederhana dalam analisis kelayakan suatu kegiatan, termasuk usahatani dalam nilai diskonto periode tertentu di luar aspek moneter (Rijiravanich, 2010 dan Gittinger, 1982). Adapun formula perhitungannya adalah sebagai berikut:

dimana:

$$
\mathrm{RCR}=\frac{\mathrm{Y}}{\mathrm{C}}=\frac{\sum_{\mathrm{n}} \mathrm{P}_{\mathrm{i}} \mathrm{Q}_{\mathrm{i}}}{\sum_{\mathrm{n}} \mathrm{P}_{\mathrm{i}} \mathrm{X}_{\mathrm{i}}}
$$

$R C R=$ perbandingan antara total penerimaan dan total biaya usahatani padi

$\mathrm{Y}=$ total penerimaan usahatani padi

$\mathrm{C}=$ total biaya usahatani padi

$\mathrm{P}_{\mathrm{i}} \quad=$ harga produksi usahatani padi

$\mathrm{Q}_{\mathrm{i}} \quad=$ produksi usahatani padi

$\mathrm{P}_{\mathrm{i}} \quad=$ harga sarana produksi usahatani padi ke-i $(i=1,2$, n)

$\mathrm{X}_{\mathrm{i}}=$ kuantitas sarana produksi usahatani padi ke-i $(i=1,2, \ldots . ., n)$

Hasil dari perhitungan formula $R C R$ menunjukkan tiga indikasi. Pertama, jika nilai $R C R$ di atas satu $(R C R>1)$, maka usahani termasuk layak diusahakan. Kedua, jika nilai $R C R$ sama dengan satu $(R C R=1)$, maka usahatani tergolong cukup layak diusahakan. Ketiga, jika nilai $R C R$ di bawah satu $(R C R<1)$, maka usahatani kurang layak diusahakan.

\section{HASIL DAN PEMBAHASAN}

\section{Keragaan Umum Usahatani Padi}

Provinsi Sulawesi Tengah memiliki luas wilayah administratif 680.330 hektar, dimana sekitar 159.382 hektar $(23,4 \%)$ diantaranya merupakan lahan sawah. Kendati Sulawesi Tengah tidak termasuk sentra produksi utama padi di Indonesia, keberadaan provinsi ini tetap strategis sebagai penyangga produksi beras nasional.

Tanaman padi sawah di Provinsi Sulawesi Tengah dibudidayakan dua kali musim tanam dalam setahun. Jadwal musim tanam pertama berlangsung antara bulan November/Desember hingga bulan Maret/April, sedangkan musim tanam kedua mulai bulan Juni/Juli sampai dengan bulan September/Oktober. Dengan kata lain, indeks pertanaman (IP) padi sawah di provinsi ini masih belum optimal (IP 200). Padahal secara teknis, IP dapat ditingkatkan menjadi empat kali musim tanam dalam setahun (IP 400) dengan pola tanam padi-padi-padi-padi (Supriatna, 2012).

Lima kabupaten masing-masing Parigi Moutong, Banggai, Sigi, Poso, Donggala, dan Tolitoli tercatat memiliki luas tanam terbesar yang sekaligus menjadikan keenam kabupaten tersebut sebagai sentra produksi padi utama di Provinsi Sulawesi Tengah. Total luas tanam musim tanam pertama sedikit lebih tinggi dibandingkan dengan total luas tanam musim tanam kedua. Dengan rataan penggunaan benih 25 kilogram per hektar, maka jumlah kebutuhan benih padi sawah adalah sekitar 5.288,78 ton per tahun dengan rincian masingmasing $2.979,03$ ton dan $2.309,75$ ton pada musim tanam pertama dan musim tanam kedua (Tabel 1). 
M. Iqbal dan M. Afif Juradi: Komparasi analisis kelayakan usahatani ...

Tabel 1. Luas Tanam dan Kebutuhan Benih Padi di Provinsi Sulawesi Tengah, 2012-2013

\begin{tabular}{lrrrrrr}
\hline \multirow{2}{*}{ Kabupaten/Kota } & \multicolumn{2}{c}{ Musim Tanam I } & \multicolumn{2}{c}{ Musim Tanam II } & \multicolumn{2}{c}{ Jumlah } \\
\cline { 2 - 7 } & Luas (ha) & \multicolumn{1}{c}{ Benih (ton) } & Luas (ha) & Benih (ton) & Luas (ha) & Benih (ton) \\
\hline Parigi Moutong & 25.782 & 644,55 & 22.757 & 568,93 & 48.539 & $1.213,48$ \\
Banggai & 19.054 & 476,35 & 20.518 & 512,95 & 39.572 & 989,30 \\
Sigi & 19.132 & 478,30 & 13.438 & 335,95 & 32.57 & 814,25 \\
Poso & 14.271 & 356,78 & 10.119 & 252,98 & 24.39 & 609,75 \\
Donggala & 12.792 & 319,80 & 10.095 & 251,38 & 22.887 & 572,18 \\
Tolitoli & 12.543 & 313,58 & 8.274 & 206,85 & 20.817 & 520,43 \\
Morowali & 9.538 & 238,45 & 3.892 & 97,30 & 13.43 & 335,75 \\
Buol & 2.936 & 73,40 & 1.673 & 41,83 & 4.609 & 115,23 \\
Tojo Unauna & 2.342 & 58,55 & 892 & 22,30 & 3.234 & 80,85 \\
Bangkep & 511 & 12,78 & 505 & 12,63 & 1.016 & 25,40 \\
Palu & 260 & 6,50 & 227 & 5,68 & 487 & 12,18 \\
\hline Sulawesi Tegah & 119.161 & $2.979,03$ & 92.39 & $2.309,75$ & 211.551 & $5.288,78$ \\
\hline
\end{tabular}

Sumber: DPTPH Sulteng, 2013

Tabel 2 Realisasi Luas Penangkaran, Produksi, dan Label Benih Padi di Provinsi Sulawesi Tengah, 2013

\begin{tabular}{lcccc}
\hline \multicolumn{1}{c}{ Uraian } & Benih Dasar & Benih Pokok & Benih Sebar & \multicolumn{1}{c}{ Jumlah } \\
\hline Luas penangkaran (ha) & 15,45 & 258,13 & 809,17 & $1.083,35$ \\
Produksi benih (kg) & 35.680 & 512.495 & 948.315 & 1.496 .490 \\
Benih berlabel (kg) & 35.430 & 358.138 & 834.719 & 1.228 .287 \\
\hline Sumber
\end{tabular}

Sumber: BPSB, 2013

Sebagian besar $(70 \%)$ pasokan benih padi di Provinsi Sulawesi Tengah berasal dari swadaya masyarakat, sisanya $(30 \%)$ dari program bantuan pemerintah (DPTPH Sulteng, 2013). Benih padi program pemerintah merupakan jenis varietas berlabel (sertifikat) yang dipasok oleh Balai Benih Induk (BBI), Balai Benih Utama (BBU), dan produsen/penangkar benih. Di provinsi ini tercatat dua unit BBI, 17 unit BBU, dan 39 unit penangkar benih padi.

Benih yang dipasok oleh balai dan penangkar benih terdiri dari tiga klasifikasi yaitu benih dasar (foundation seed/FS), benih pokok (stock seed/SS), dan benih sebar (extension seed/ES) dengan label masingmasing putih, ungu, dan biru. Realisasi luas penangkaran, produksi, dan label benih padi di Prov. Sulawesi Tengah disajikan pada Tabel 2.

Dari Tabel 2 di atas dapat diperhatikan bahwa jumlah produksi penangkaran benih padi di Provinsi Sulawesi Tengah adalah sekitar 1.496,49 ton per tahun. Dari jumlah produksi penangkaran tersebut tersebut, hanya 1.228,29 ton (82\%) yang berlabel (lulus sertifikasi). Jika dibandingkan dengan jumlah kebutuhan benih di provinsi ini (lebih kurang 5.288,78 ton/tahun), maka proporsi penyediaan benih dari penangkaran dan yang berlabel masingmasing hanya sekitar 28,30 persen dan 23,22 persen (agregat 25,76\%). Sisanya berasal dari swadaya masyarakat, yaitu berupa seleksi hasil panen usahatani padi konsumsi musim tanam sebelumnya untuk dijadikan benih padi musim tanam berikutnya, atau dari pertukaran benih padi antar petani. Proporsi tersebut jelas kurang untuk mendukung peningkatan produktivitas padi sawah di provinsi setempat. Hal demikian didasari bahwa penggunaan benih padi berlabel (sertifikasi) yang dihasilkan dari proses penangkaran merupakan salah satu kunci pokok dalam mendukung peningkatan produksi padi.

Dari sisi jenis tanaman, terdapat delapan varietas padi yang dominan digunakan petani di Provinsi Sulawesi Tengah. Kedelapan varietas tersebut adalah Ciherang, Mekongga, Ciliwung, Cigeulis, Cisantana, Way Apoburu, Towuti, dan Inpari. Ciherang merupakan 


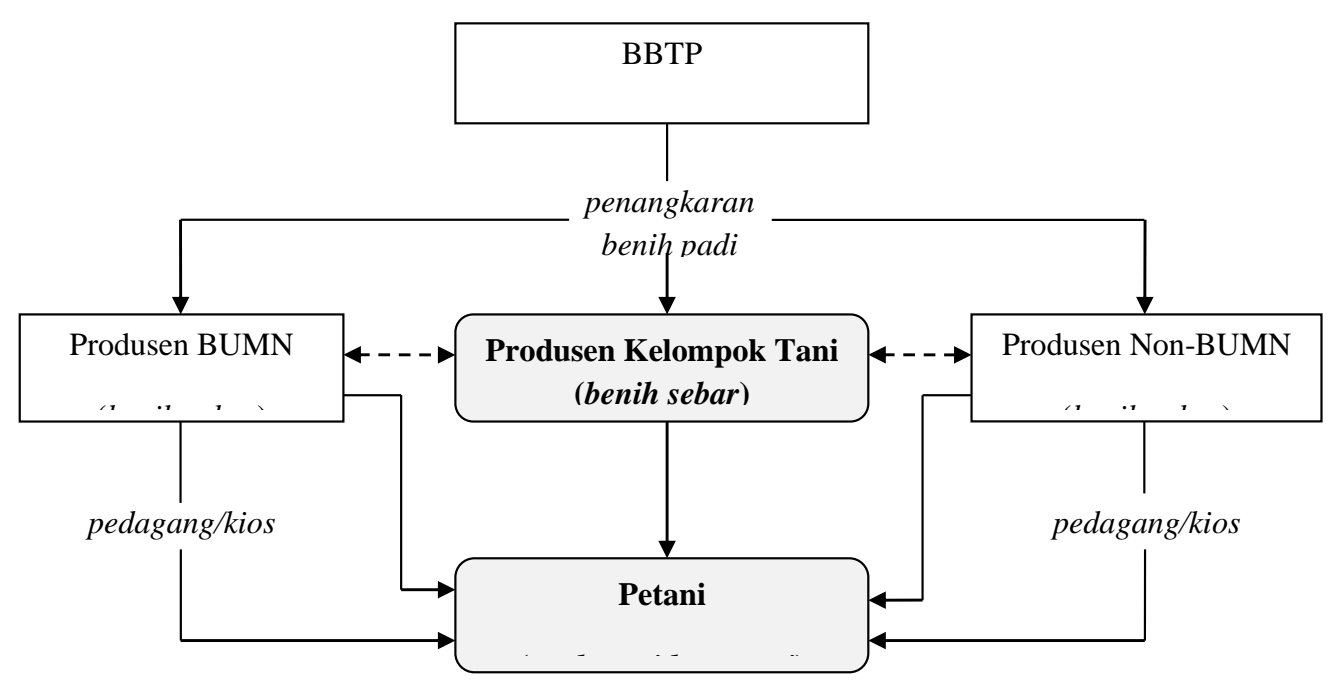

Gambar 2 Alur Distribusi Benih Padi Bersertifikat di Provinsi Sulawesi Tengah (Sumber: Data Primer, 2013)

varietas yang paling banyak digunakan, yaitu dengan pangsa sekitar 80 persen. Khusus untuk Inpari, varietas ini merupakan produk penelitian Badan Penelitian dan Pengembangan Pertanian (Balitbangtan) yang kajian penyebarannya di Provinsi Sulawesi Tengah dilaksanakan oleh Balai Pengkajian Teknologi Pertanian (BPTP) setempat melalui Unit Pengelola Benih Sebar (UPBS). Beberapa varietas Inpari yang sudah disebarluaskan antara lain Inpari-4, Inpari-13, Inpari-14, Inpari-5, dan Inpari-20.

Secara skematis alur distribusi benih padi bersertifikat di Provinsi Sulawesi Tengah disajikan pada Gambar 2. Dapat diperhatikan bahwa terdapat empat pelaku utama penangkaran yang selanjutnya disebut sebagai produsen benih padi, yaitu masing-masing: (1) BUMN (Badan Usaha Milik Negara) seperti PT Sang Hyang Seri dan PT Pertani; (3) NonBUMN (swasta); dan (4) kelompok tani. Sumber pengadaan benih pokok padi untuk penangkaran berasal BBTP (Balai Benih Tanaman Pangan). Baik produsen BUMN maupun produsen Non-BUMN memiliki hubungan kerjasama kegiatan (kemitraan) penangkaran benih padi dengan kelompok tani. Implementasinya, pihak BUMN atau NonBUMN memasok benih padi kepada kelompok tani untuk ditangkarkan dan hasil tangkaran diserahkan kepada pihak pemasok dalam bentuk kerjasama kegiatan berlandaskan transaksi perjanjian bisnis.
Pedistribusian benih sebar padi dilaksanakan baik secara langsung maupun tidak langsung ke petani pengguna. Distribusi tidak langsung melibatkan pedagang/kios. Dalam artikel ini pembahasan hanya fokus pada penangkaran benih padi oleh kelompok tani yang selanjutnya didistribusikan kepada petani (usahatani padi konsumsi).

\section{Usahatani Penangkaran Benih Padi}

Penangkaran benih padi dilakukan dua kali dalam setahun, yaitu mengikuti pola tanam setempat (musim tanam pertama dan musim tanam kedua). Penangkaran benih padi disesuaikan dengan keinginan dan permintaan petani. Empat varietas padi yang paling banyak diinginkan dan diminta petani adalah Ciliwung, Ciherang, Mekongga, dan Ciherang. Varietasvarietas tersebut memiliki beberapa kriteria, antara lain: (1) tahan terhadap serangan organisme pengganggu tanaman (OPT); (2) produksi optimal; (3) rendemen tinggi; dan (4) rasa nasi enak.

Ada beberapa catatan penting terkait dengan teknis usahatani penangkaran benih padi. Pertama, penerapan rekomendasi teknologi spesifik lokasi dengan tujuan untuk mendapatkan kualitas yang baik (sertifikasi). Kedua, pencegahan terhadap Campuran Varietas Lain (CVL) oleh Pengawas Benih Tanaman (PBT). Ketiga, penerapan sistem "roguing". Keempat, pemeriksaan laboratorium dan pemberian sertifikasi benih (label biru). 
Salah satu syarat benih berkualitas adalah memiliki tingkat kemurnian genetik yang tinggi. Oleh karena itu "roguing" perlu dilakukan dengan cara membuang rumpunrumpun tanaman yang ciri-cirinya menyimpang (off type) dari karakteristik morfologis benih. Khusus untuk tanaman padi, sifat-sifat fisik tanaman padi yang diamati pada saat roguing meliputi tipe pertumbuhan, kehalusan daun, warna helai daun, warna lidah daun, warna tepi daun, warna pangkal batang, bentuk/tipe malai, bentuk gabah, bulu pada ujung gabah, warna ujung gabah, dan warna gabah (BPTP Jabar, 2009).

Paling tidak, roguing dalam penangkaran benih padi dilaksanakan sebanyak tiga kali. Urutan ketiga roguing tersebut adalah: (1) roguing-1 pada fase vegetatif (setelah penyiangan pertama), dimana pada fase ini tanaman padi sedang aktif membentuk anakan; (2) roguing-2 pada akhir fase vegetatif dan awal fase generatif, yaitu pada saat tanaman padi mulai berbunga; (3) roguing-3 pada saat pematangan bulir sebelum panen.

\section{Kelayakan Usahatani Penangkaran Benih Padi}

Rekapitulasi analisis kelayakan usahatani penangkaran benih padi di Provinsi Sulawesi Tengah tersaji pada Tabel 3. Lengkapnya dapat diperhatikan pada Lampiran Tabel 1. Fokus analisis adalah musim tanam pertama (MT I) dan musim tanam kedua (MT II). Biaya usahatani terdiri dari tiga komponen utama, yaitu: (1) sarana produksi (benih, pupuk, dan racun pembasimi hama/penyakit); (2) tenaga kerja (pengolahan lahan, penanaman, pemeliharaan, dan panen); dan (3) perbenihan (penjemuran, pengolahan, sertifikasi, dan pengemasan).

Secara agregat, proporsi biaya usahatani tertinggi adalah untuk upah tenaga kerja $(56,84 \%)$, diikuti oleh biaya sarana produksi $(23,75 \%)$ dan perbenihan $(19,41 \%)$. Rataan jumlah penggunaan benih adalah sekitar 25 kilogram per hektar dengan harga Rp 6.100 per kilogram. Sebagai catatan, sistem penanaman usahatani penangkaran benih padi dilakukan melalui persemaian dan tanam pindah (tapin).

Produksi gabah kering panen (GKP) usahatani penangkaran benih padi masing- masing 4.750 kilogram per hektar (MT I), 4.550 kilogram per hektar (MT I), dan 4.650 kilogram per hektar (agregat). Dengan rendemen sekitar 80 persen dari gabah kering panen (GKP), rataan produksi benih yaitu 3.720 kilogram per hektar. Produksi benih padi musim tanam pertama $(3.800 / \mathrm{kg})$ lebih tinggi dari pada produksi benih padi musim tanam kedua (3.640/kg). Harga produksi (benih padi) adalah sekitar Rp 5.500 per kilogram.

Berdasarkan kalkulasi biaya dan penerimaan, usahatani penangkaran benih padi cukup layak diusahakan. Hal tersebut diindikasikan oleh perbandingan antara penerimaan dan biaya (Revenue Cost Ratio/RCR) pada musim tanam pertama $(1,88)$ dan musim tanam kedua $(1,71)$, atau rata-rata $(1,79)$. Artinya, setiap $\mathrm{Rp} 1$ penerimaan usahatani penangkaran benih padi memerlukan biaya antara $\mathrm{Rp} 0,71$ hingga $\mathrm{Rp} 0,88$.

\section{Usahatani Padi Konsumsi}

Secara teknis, unit produksi usahatani padi konsumsi tidak selengkap unit produksi usahatani penangkaran benih padi. Rataan keperluan bibit usahatani padi konsumsi (50 $\mathrm{kg} / \mathrm{ha}$ ) dua kali lebih tinggi dibandingkan penggunaan bibit usahatani penangkaran benih padi $(25 \mathrm{~kg} / \mathrm{ha})$. Hal tersebut karena sistem penanaman usahatani padi konsumsi dilakukan dengan tiga cara yaitu tanam pindah (tapin), tanam benih langsung (tabela), dan hambur benih langsung (hambela) yang notabene lebih banyak memerlukan benih. Sementara itu, penanaman usahatani penangkaran benih padi dilaksanakan dengan cara tanam pindah (tapin) yang kuantitas penggunaanya relatif terukur. Rataan harga benih usahatani padi konsumsi juga lebih murah $(\operatorname{Rp} 5.500 / \mathrm{kg})$ dibandingkan rataan harga benih usahatani penangkaran padi (Rp 6.100/kg). Murahnya harga benih usahatani padi konsumsi karena penggunaannya bervariasi menurut jenis dan kualitas.

\section{Kelayakan Usahatani Padi Konsumsi}

Unit produksi yang cukup membedakan antara usahatani padi konsumsi dengan usahatani penangkaran benih padi adalah dalam hal perlakuan perbenihan. Unit produksi perlakuan perbenihan hanya tardapat pada usahatani penangkaran benih padi. Secara teknis unit produksi lainnya boleh dikatakan tidak jauh berbeda, namun secara ekonomi agregasi 
M. Iqbal dan M. Afif Juradi: Komparasi analisis kelayakan usahatani ...

Tabel 3. Rekapitulasi Analisis Kelayakan Usahatani Penangkaran Benih Padi di Provinsi Sulawesi Tengah, 2012/2013 (Rp/hektar)

\begin{tabular}{lrrr}
\hline \multicolumn{1}{c}{ Uraian } & Musim Tanam I & Musim Tanam II & \multicolumn{1}{l}{ Rataan } \\
\hline Biaya: & & & \\
Sarana produksi & 2.701 .500 & 2.727 .500 & $2,714,500$ \\
Tenaga kerja & 6.305 .000 & 6.685 .000 & $6,495,000$ \\
Perbenihan & 2.131 .000 & 2.305 .000 & $2,218,000$ \\
Total biaya & 11.137 .500 & 11.717 .500 & $11,427,500$ \\
Penerimaan & 20.900 .000 & 20.020 .000 & $20,460,000$ \\
\hline Revenue Cost Rasio $($ RCR $)$ & 1,88 & 1,71 & 1,80 \\
\hline
\end{tabular}

Sumber: Data Primer, 2013

Tabel 4. Rekapitulasi Analisis Kelayakan Usahatani Padi Konsumsi di Provinsi Sulawesi Tengah, 2012/2013 (Rp/hektar)

\begin{tabular}{lrrr}
\hline \multicolumn{1}{c}{ Uraian } & Musim Tanam I & Musim Tanam II & \multicolumn{1}{c}{ Rataan } \\
\hline Biaya: & & & \\
Sarana produksi & 2.725 .000 & 2.800 .000 & 2.762 .500 \\
Tenaga kerja & 5.370 .000 & 5.900 .000 & 5.635 .000 \\
Total biaya & 8.095 .000 & 8.700 .000 & 8.397 .500 \\
Penerimaan & 12.989 .950 & 15.118 .850 & 14.054 .400 \\
\hline Revenue Cost Rasio $($ RCR $)$ & 1,60 & 1,74 & 1,67 \\
\hline
\end{tabular}

Sumber: Data Primer, 2013

Tabel 5. Rekapitulasi Komparasi Analisis Usahatani Penangkaran Benih Padi dan Usahatani Padi Konsumsi di Provinsi Sulawesi Tengah, 2012/2013 (per kilogram)

\begin{tabular}{lrrrrrr}
\hline \multicolumn{1}{c}{ Uraian } & \multicolumn{3}{c}{ Penangkaran Benih } & \multicolumn{3}{c}{ Padi Konsumsi } \\
& MT I & MT II & Rataan & MT I & MT II & Rataan \\
\hline Produksi (kg/ha): & & & & & & \\
$\quad$ Gabah kering panen (GKP) & 4.750 & 4.550 & 4.650 & 4.259 & 4.957 & 4.608 \\
$\quad$ Benih & 3.800 & 3.640 & 3.720 & 0 & 0 & 0 \\
Biaya (Rp/kg) & 2.931 & 3.219 & 3.075 & 1.901 & 1.755 & 1.828 \\
Penerimaan (Rp/kg) & 5.476 & 5.500 & 5.488 & 3.050 & 3.050 & 3.050 \\
Revenue Cost Ratio $($ RCR $)$ & 1,88 & 1,71 & 1,80 & 1,60 & 1,74 & 1,67 \\
\hline Sumber: data primer
\end{tabular}

Sumber: data primer, 2013

biayanya tidak sama. Hal demikian karena investasi yang diperlukan untuk usahatani padi konsumsi tidak setinggi investasi untuk usahatani penangkaran benih padi. Secara agregat, investasi usahatani padi konsumsi lebih rendah sekitar 15 persen dari pada usahatani penangkaran benih padi.

Secara agregat, produksi usahatani padi konsumsi sedikit lebih rendah dibandingkan produksi usahatani penangkaran benih padi. Namun harga produksinya jauh berbeda, dimana harga produksi usahatani padi konsumsi (Rp 5.500/kg) lebih rendah dari pada harga produksi usahatani penangkaran benih

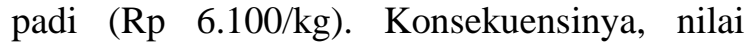
produksi usahatani padi konsumsi juga lebih rendah. Akan tetapi, usahatani padi konsumsi tetap layak dengan nilai $R C R$ masing-masing 1,60 (musim tanam pertama) dan 1,74 (musim tanam kedua), atau secara agregat sekitar 1,67 (Tabel 4 dan Lampiran Tabel 2). 


\section{Komparasi Kelayakan Usahatani Penangkaran Benih dan Padi Konsumsi}

Sebagaimana telah dibahas sebelumnya bahwa kelayakan usahatani penangkaran benih padi sedikit lebih baik dibandingkan dengan kelayakan usahatani padi konsumsi. Komparasi kelayakan kedua usahatani tersebut dalam aspek yang lebih mikro yaitu berdasarkan kalkulasi per kilogram menunjukkan bahwa penerimaan usahatani penangkaran benih padi lebih tinggi dibandingkan dengan kalkulasi yang sama pada usahatani padi konsumsi (Tabel 5).

Dari Tabel 5 dapat diperhatikan bahwa rataan penerimaan usahatani penangkaran benih padi (Rp 5.488/kg) jauh lebih tinggi dari pada penerimaan usahatani padi konsumsi (Rp $3.050 / \mathrm{kg}$ ). Dengan kata lain, usahatani penangkaran benih padi memiliki prospek yang cukup bagus. Akan tetapi, pasang surut kegiatan usahatani penangkaran benih padi di lokasi penelitian antara lain dipengaruhi oleh permintaan terhadap benih padi dari petani dan pengguna lainnya, eksistensi program pemerintah dalam pengadaan benih padi, dan kemampuan modal usaha dari penangkar sendiri. Adakalanya terjadi distorsi fenomena dimana beberapa petani penangkar menggiling benih padi menjadi beras atau melakukan pertukaran (barter) benih padi dengan gabah kering giling untuk konsumsi. Fenomena tersebut biasanya dipicu apabila terjadi kelebihan cadangan karena rendahnya permintaan, sementara pada waktu yang bersamaan harga beras cukup tinggi.

\section{KESIMPULAN DAN IMPLIKASI KEBIJAKAN}

\section{Kesimpulan}

Dari hasil pembahasan di atas dapat ditarik beberapa kesimpulan pokok tentang usahatani penangkaran benih padi dan usahatani padi konsumsi di Provinsi Sulawesi Tengah. Pokok-pokok kesimpulan tersebut adalah sebagai berikut:

1. Pola tanam padi di provinsi Sulawesi Tengah adalah padi-padi, meliputi musim tanam pertama (November/DesemberMaret/April) dan musim tanam kedua (Juni/Juli-September/Oktober). Sekitar 1-2 bulan diantara kedua jadwal musim tanam tersebut, lahan tidak diusahakan (bera).
2. Kebutuhan benih padi di Provinsi Sulawesi Tengah adalah sekitar 5.289 ton per tahun dengan rincian masing-masing 2.979 ton dan 2.310 ton pada musim tanam pertama dan musim tanam kedua. Sejatinya Sulawesi Tengah tidak kekurangan benih padi, tetapi hanya mengalami difisit benih padi berlabel (sertifikasi) karena proporsi pasokannya baru mencapai sekitar 25,76 persen dari total kebutuhan benih padi di provinsi ini.

3. Baik usahatani penangkaran benih padi maupun usahatani padi konsumsi samasama layak diusahakan dengan agregasi perbandingan antara penerimaan dengan biaya (revenue cost ratio/RCR) masingmasing sekitar 1,80 dan 1,67. Komparasi analisis kelayakan antara kedua usahatani tersebut menunjukkan bahwa penerimaan usahatani penangkaran benih padi (Rp $5.488 / \mathrm{kg}$ ) jauh lebih tinggi dari pada penerimaan usahatani padi konsumsi $(\mathrm{Rp}$ $3.050 / \mathrm{kg}$ ).

4. Kendati usahatani penangkaran benih padi di Provinsi Sulawesi Tengah cukup prospektif, eksistensi dan keberlanjutannya dipengaruhi oleh beberapa hal. Pertama, permintaan terhadap benih padi dari petani dan pengguna lainnya. Kedua, eksistensi program pemerintah dalam pengadaan benih padi. Ketiga, kemampuan modal usaha dari penangkar sendiri. Oleh karena itu, jaminan permintaan dan harga yang kondusif merupakan dua aspek penting dalam menunjang kelangsungan usahatani penangkaran benih padi di Provinsi Sulawesi Tengah.

\section{Implikasi Kebijakan}

Implikasi dari hasil penelitian meliputi beberapa hal mendasar terkait dengan kebijakan perbenihan padi, khususnya di Sulawesi Tengah. Implikasi kebijakan perbenihan padi di provinsi ini meliputi beberapa hal berikut:

1. Berdasarkan dukungan potensi yang ada, perlu diupayakan peningkatan indeks pertanaman (IP) padi di Provinsi Sulawesi Tengah. Implementasinya dapat ditempuh melalui investasi pengembangan infrastruktur dan sekaligus penyaluran benih padi yang memenuhi syarat kriteria enam tepat (jumlah, mutu, waktu, varietas, 
tempat, dan harga). Selain itu juga perlu dukungan rekayasa teknologi dan sosial dalam dimensi ruang dan waktu sehingga optimalisasi indeks pertanaman dapat dilaksanakan dalam rangka peningkatan produksi dan pendapatan petani padi sawah.

2. Pemenuhan kebutuhan benih padi unggul dan bermutu di Provinsi Sulawesi Tengah merupakan tanggungjawab langsung insitusi-institusi perbenihan setempat. Koordinasi diantara berbagai institusi perbenihan tersebut perlu ditingkatkan dengan peran sentral Dinas Pertanian setempat sebagai garda terdepan (leading sector). Selama ini ada kesan bahwa eksistensi dan kiprah institusi-institusi perbenihan di Provinsi Sulawesi Tengah "sudah sejalan" tetapi "belum beriringan" dalam mengemban pelayanan sistem perbenihan kepada pengguna (petani).

3. Program pengadaan benih padi di Provinsi Sulawesi Tengah tidak dapat dilepaskan dari agenda nasional. Kendati demikian, pihak daerah memiliki porsi untuk menyuarakan, mengorganisir, dan sekaligus melaksanakan kepentingan yang bersifat spesifik lokasi. Untuk itu perlu kiranya dibentuk suatu wadah berupa "Forum Perbenihan" yang beranggotakan para pemangku kepentingan perbenihan dengan koordinator (mediasi, komunikasi, dan fasilitasi) Dinas Pertanian setempat. Alternatif pola pengadaan benih padi yang bersifat spesifik lokasi perlu difikirkan, tetapi implementasinya sinkron dengan kebijakan nasional (bukan mengikuti pola di Jawa yang kondisinya relatif cukup berbeda).

4. Khusus untuk penangkar benih padi, perlu dibentuk suatu wadah organisasi seperti "Asosiasi Penangkar Benih". Tujuannya adalah untuk memadupadankan kepentingan para penangkar baik dalam hal kelangsungan usaha, jalinan kemitraan, maupun negosiasi pemasaran benih. Asosiasi tersebut harus berlandaskan sikap profesionalisme kegotongroyongan yang dibentuk dari aspirasi para penangkar benih padi, dipimpin oleh personal yang memiliki integritas tinggi, dan bebas dari kepentingan politik.

\section{DAFTAR PUSTAKA}

BPSB Sulteng. 2013. Realisasi Luas Penangkaran, Produksi, dan Label Benih Padi di Provinsi Sulawesi Tengah. Bagian Sertifikasi Benih Tanaman Pangan, Balai Pengawasan dan Sertifikasi Benih Provinsi Sulawesi Tengah. Palu.

BPTP Jabar. 2009. Petunjuk Teknis Penangkaran Benih Padi. Balai Pengkajian Teknologi Pertanian Provinsi Jawa Barat. Lembang.

BPTP Sulteng. 2013. Mapping Potensi Balai Benih Induk (BBI) dan Balai Benih Utama (BBU) dalam Penyediaan Benih Berkualitas di Provinsi Sulawesi Tengah. Balai Pengkajian Teknologi Pertanian Provinsi Sulawesi Tengah. Palu.

Ditjentan Pangan. 2015. Pedoman Teknis Pemberdayaan Penangkar Benih Tahun Anggaran 2015. Direktorat Jenderal Tanaman Pangan. Kementerian Pertanian. Jakarta.

DPTPH Sulteng. 2013. Luas Tanaman Padi Sawah Musim Tanam Pertama dan Kedua di Provinsi Sulawesi Tengah Tahun 2012 dan 2013. Dinas Pertanian Tanaman Pangan dan Hortikultura Provinsi Sulawesi Tengah. Palu.

Gittinger, J. P. 1982. Economic Analysis of Agricultural Projects. Johns Hopkins University Press. Baltimore. USA.

Kementan 2009. Rancangan Rencana Strategi Kementerian Pertanian Tahun 20102014. Kementerian Pertanian. Jakarta.

Pemerintah RI. 1992. Undang-Undang Republik Indonesia Nomor 12 Tahun 1992 tentang Budidaya Tanaman. Pemerintah Republik Indonesia. Jakarta.

Rijiravanich, V. 2010. Benfit Cost Ratio. Siam University. Bangkok. Thailand.

Supriatna, A. 2012. Meningkatkan Indeks Pertanaman Padi Sawah Menuju IP 400. Jurnal Agrin, Volume 16, Nomor 1, Tahun 2012: 1-18 (ISSN: 1410-0029). Fakultas Pertanian, Universitas Jenderal Soedirman. Purwokerto. 


\section{LAMPIRAN}

Tabel 1 Analisis Kelayakan Usahatani Penangkaran Benih Padi Musim Tanam Pertama dan Kedua di Provinsi Sulawesi Tengah, 2012/2013 (hektar)

\begin{tabular}{|c|c|c|c|c|c|c|c|c|c|}
\hline Uraian & \multicolumn{3}{|c|}{ Musim Tanam Pertama } & \multicolumn{3}{|c|}{ Musim Tanam Kedua } & \multicolumn{3}{|c|}{ Rataan } \\
\hline \multicolumn{10}{|l|}{ Sarana produksi: } \\
\hline Benih & $25 \mathrm{~kg}$ & 6.100 & 152.500 & $25 \mathrm{~kg}$ & 6.100 & 152.500 & $25 \mathrm{~kg}$ & 6.100 & 152.500 \\
\hline Pupuk phonska & $300 \mathrm{~kg}$ & 2.500 & 750.000 & $300 \mathrm{~kg}$ & 2.500 & 750.000 & $300 \mathrm{~kg}$ & 2.500 & 750.000 \\
\hline Pestisida/rodentisida & & & 880.000 & & & 900.000 & & & 890.000 \\
\hline Herbisida & & & 519.000 & & & 525.000 & & & 522.000 \\
\hline Sub-total & & & 2.701 .500 & & & 2.727 .500 & & & 2.714 .500 \\
\hline Aplikasi herbisida & $1 \mathrm{HOK}$ & 65.000 & 65.000 & $1 \mathrm{HOK}$ & 65.000 & 65.000 & $1 \mathrm{HOK}$ & 65.000 & 65.000 \\
\hline Pembuatan persemaian & $1 \mathrm{HOK}$ & 65.000 & 65.000 & $1 \mathrm{HOK}$ & 65.000 & 65.000 & $1 \mathrm{HOK}$ & 65.000 & 65.000 \\
\hline Penanaman $^{\frac{3}{3}}$ & $15 \mathrm{HOK}$ & 65.000 & 975.000 & $15 \mathrm{HOK}$ & 65.000 & 975.000 & $15 \mathrm{HOK}$ & 65.000 & 975.000 \\
\hline Pemeliharaan $^{4]}$ & $18 \mathrm{HOK}$ & 65.000 & 1.170 .000 & $20 \mathrm{HOK}$ & 65.000 & 1.300 .000 & $19 \mathrm{HOK}$ & 65.000 & 1.235 .000 \\
\hline Roguing ${ }^{5]}$ & $4 \mathrm{HOK}$ & 65.000 & 260.000 & $4 \mathrm{HOK}$ & 65.000 & 260.000 & $4 \mathrm{HOK}$ & 65.000 & 260.000 \\
\hline Panen & & & 2.250 .000 & & & 2.500 .000 & & & $2,375,000$ \\
\hline Sub-total & & & 6.305 .000 & & & 6.685 .000 & & & $6,495,000$ \\
\hline Sub-total & & & 2.131 .000 & & & 2.305 .000 & & & 2.218 .000 \\
\hline Total biaya & & & 11.137 .500 & & & 11.717 .500 & & & 11.427 .500 \\
\hline Produksi dan penerimaan ${ }^{10]}$ & $3.800 \mathrm{~kg}$ & 5.500 & 20.900 .000 & $3.640 \mathrm{~kg}$ & 5.500 & 20.020 .000 & 3.720 & 5.500 & 20.460 .000 \\
\hline Revenue Cost Ratio $(R C R)$ & & & 1,88 & & & 1,71 & & & 1.80 \\
\hline
\end{tabular}

Catatan: ${ }^{1]} \mathrm{HOK}$ (hari orang kerja); ${ }^{2]}$ bajak, garu, dan cangkul (pematang, dll.); ${ }^{3]}$ cabut bibit, caplak, dan lain-lain; ${ }^{4]}$ pemupukan, pengairan, penyiangan, pengendalian organisme pengganggu tanaman (OPT), pengairan, dan lain-lain; ${ }^{5]}$ roguing (seleksi tanaman di lapangan); ${ }^{6]}$ pengolahan gabah kering panen (GKP) ke benih; ${ }^{7]}$ termasuk blower, seed cleaner, dan lain-lain; ${ }^{81}$ termasuk pemeriksaan lapang, uji laboratorium, dan pelabelan; ${ }^{91}$ termasuk biaya pembelian karung dan kantong; ${ }^{10]}$ benih (rendemen $80 \%$ dari gabah kering panen/GKP).

Sumber: data primer, 2013

Tabel 2 Analisis Kelayakan Usahatani Padi Konsumsi Musim Tanam Pertama dan Kedua di Provinsi Sulawesi Tengah, 2012/2013 (hektar)

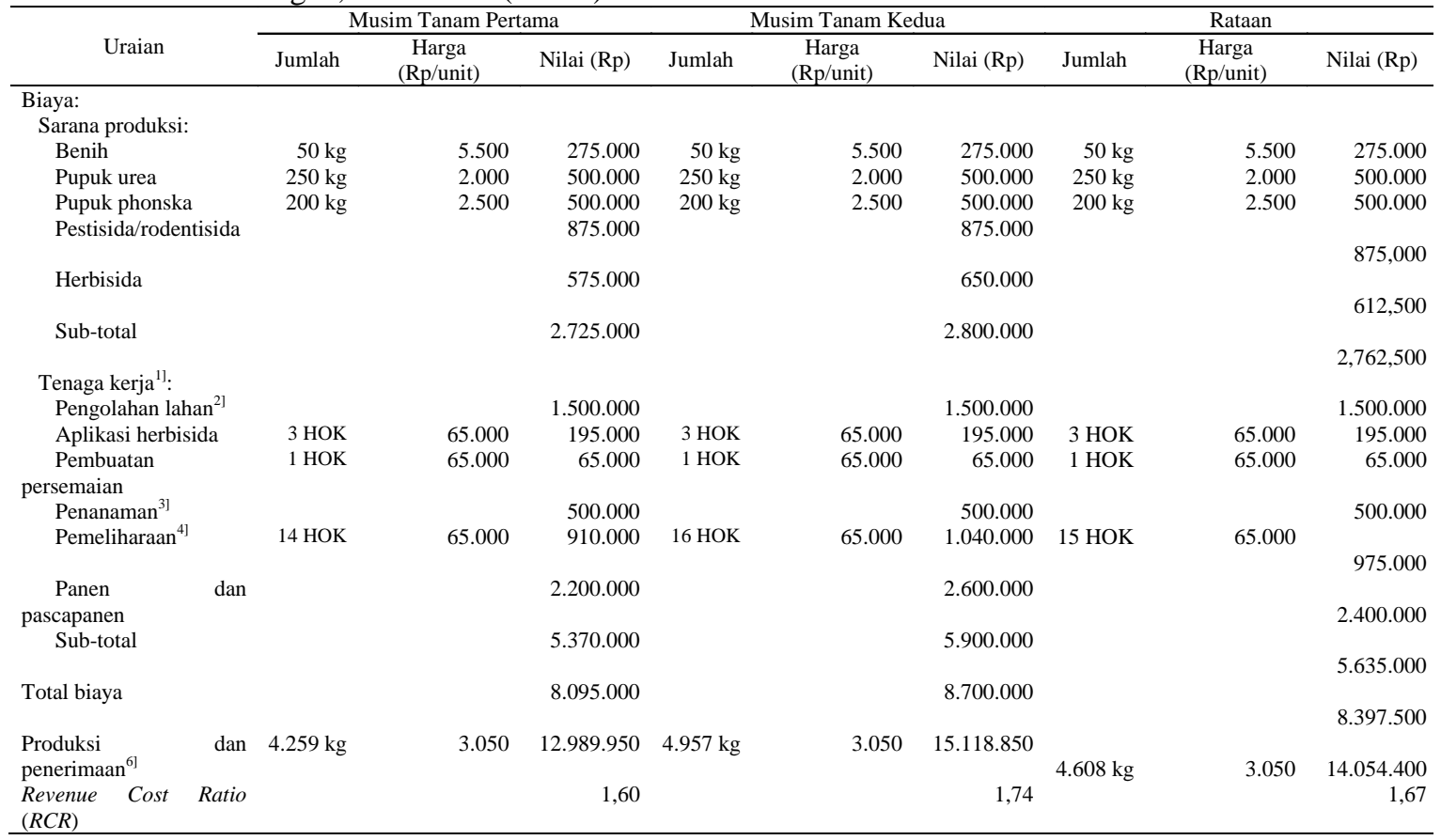

Catatan: ${ }^{1]} \mathrm{HOK}$ (hari orang kerja); ${ }^{2]}$ bajak, garu, dan cangkul (pematang, dll.); ${ }^{3]}$ cabut bibit, caplak, dan lain-lain; ${ }^{4]}$ pemupukan, pengairan, penyiangan, pengendalian organisme pengganggu tanaman (OPT), pengairan, dan lain-lain; ${ }^{5]}$ penjemuran, penyimpanan, dan lain-lain; ${ }^{6]}$ produksi GKP (gabah kering panen).

Sumber: data primer, 2013 